\title{
Students' Perspective on Cheating during the Assessment Process at Tertiary Level of Social and Political Sciences Faculty, Jenderal Soedirman University - Indonesia
}

\author{
Syaifur Rochman ${ }^{1}$, MimienAminah Sudjai'ie ${ }^{2}$ \\ ${ }^{1}$ Humanities Department of Faculty of Socio and Political Sciences, Jenderal Soedirman University, Indonesia \\ rochman_syaifur@hotmail.com \\ ${ }^{2}$ Humanities Department of Faculty of Socio and Political Sciences, Jenderal Soedirman University, Indonesia
}

\begin{abstract}
Cheating is regarded as a means to a profitable end and a way to obtain the highest grades in the tests. Nowadays, the educational system has been incraesingly growing tolerant of cheating with few punishments. An academic dishonesty becomes a problem encountered by the Indonesian students at tertiary level. It is the fact that cheating during the assessment processes has been reported by the invigilators as well as the teachers in several cases. Few researches have been conducted to see the reasons behind that. Results of this survey have indicated that some students do not see cheating as a serious offense. This study explains the reasons of cheating occurring among Jenderal Soedirman University students through a forum group discussion of cheating within Javanese culture as the major culture of the students. There are four aspects of the Javanese characters, namely gotongroyong, sadulur, damaiand rasa kekeluargaan as a frame to see the rationale behind academic dishonesty. A questionnaire of 88 undergraduate students of English Language and Literature Study Program of Faculty of Social and Political Science at Jenderal Soedirman University was undertaken to see the prevalence of these aspects when students engaged in cheating.
\end{abstract}

Keywords: Indonesian, cheating, university education, Javanese culture

\section{Introduction}

The most commonly accepted excuse for cheating among the students is a fear of not passing, which carried other, related consequences like falling behind classmates. This reasoning is applicable today within any environment (Diekhoff, et.al. 1996). Another reason is somewhat reasonable, like students see others cheating and they think they are being unfairly disadvantaged (Jones, 2001). Besides, students are nervous, have sense of obligation to the college, or no respect for the professor (Ainke, 1991). However, these reasons do not necessarily make it right to cheat in the exams.

Cases of cheating have been found at some universities in Indonesia during the examination. Records at the Humanities Departement of Jenderal Soedirman University, few students were caught cheating on exams every semester. Seemingly, students at tertiary level considers cheating in exams is trivial beacuse it commonly happens. It is likely that students today do not hold honesty in high regard. Cheating is a norm of incompetent students who are worried of the course failure. In the Indonesian's university system, a great number of cheating scandals can be seen in an attitude and academic dishonesty. It is likely that several university graduates are underqualified for the positions they hold because of cheating.

It is debatable that cheating is influenced by the beliefs of local culture that cause negative effects upon students. In Jenderal Soedirman University, most students are Javanese. Therefore, its is essential to examine aspects of Javanese culture which relate to social relationship because those aspects are the foundation of Javanese students' way of thinking. In this report, an examination into aspects of Javanese society can be made to discover the reasons and extent of its prevalence among students in Jenderal Soedirman University. 
A survey of 88 students of English Language and Literature Study Programme at Jenderal Soedirman University is conducted. After that, an in-depth discussion is done with them on their experiences regarding cheating. At last, some conclusions about cheating in Jenderal Soedirman University can be drwan. It is hoped that cheating will eventually be regarded as a serious problem by students in tertiary level.

\section{Literature Review}

\subsection{Cheating}

Jones (2001) explains that cheatingis any deceitful or fraudulent attempt to evade rules, standards, practices, customs, mores, and norms to gain an unfair advantage or to protect someone who has done so. Furthermore, Howard and Davies (2009) elaborate that cheating includes giving or receiving information during an exam, like tests, assessments, and quizzes, whether delivered in a classroom setting or on line. Besides, McCabe and Trevino (1993) mention that cheating covers using unauthorized material, like notes, during any exam. Other academic dishonest conducts are, like Haines et.al. (1986) mention, unauthorized dissemination or receipt of exams, exam materials, contents, or answer keys in written form. Aiken (1991) also states an example of cheating by taking an exam or writing a paper for another student.

Cheating is reargded as a series of practices that is illegal and unethical because it violates the regulations set by the institution (Newsteadet.al., 1996). Academically, Diekhoffet.al. (1999)see cheating is considered as acts committed by students that deceive, mislead, or fool the teacher into thinking that the other students' academic work submitted is his or her own work. The issues on the degree of cheating can be explored more (Diekhoffet.al., 1996). It is possible that other people assist the students in completion of homework without the teacher's knowledge. Nevertheless, a classification of cheating is typically understood by students.

\subsection{The Javanese}

People who live in the central and eastern parts of Java island are Javanese. Amongst the regional ethical groups in Indonesia, the Javanese are the biggest one (Koentjaraningrat, 1990). There are several linguistic sub-areas of Javanese in which speakers speak in distinctive dialects (Suharno, 1982).

In the Javanese language, the relationship between speaker and interlocutor is always expressed (SmithHefner, 1988). The speech level is divided into three main froms: kromo, madyo, and ngoko: the formal, intermediate, and informal respectively (Poedjosoedarmo, 1982). The choice of these forms is determined by several factors such as social status, age, degree of acquaintace, family environment, and extended family kinship.

Javanese has its own alphabet system which consits of twenty letters. Koentjaraningrat (1990) states that the Javanese scrip is adapted from the Sanskrit Deawanagi script of South India. Today, most Javanese publications are written in Roman script. There is a trend for the nesJavaenese generation to be unable to read and write Javanese scrpit.

\subsection{Javanese culture}

According to the Javanese etiqutte, one is expected to behave properly when one interacts with another (Guness, 1986). The most important element of social inetractions in Java is respect (urma) which is shown by posture position, getures, and tone of voice, term of address, and the language level spoken (Geertz, 1961). The Javanese respect can be portrayed by three Javanese words: wedi, isin, and sungkanwhich cause 
someone to behave respectfullly (Sairin, 1982). Wedi means 'afraid' in both the physical and social sense with respect to unpleasant consequences of an action. Isin refers to the feeling of shame, shyness, embarrassment, and guilt. Meanwhile, sungkan is explained as a feeling og respectful politeness before a superior or an unfamiliar equal.

The ideal situation in the Javanese social realtions is rukun which is defined as aspects of mutual assitance (gotongroyong, saling bantu membantu), intimacy with neighbour (akrab, sadulur), social harmony (tenangmasyarakat, damai, aman), and family-like solidarity (rasa kekeluargaan) (Anderson, 1965). In other words, the Javanese value in community interaction is that one dose not live alone in the world.

\section{Methods}

Surveys were conducted to obtain the data of this research. There were 88 students of the second year or the fourth semester in English Language and Literature Program, Faculty of Political and Social Scienes, Jenderal Soedirman University. Students were from the two paralel classes. They were asked to participate in the study by voluntarily completing a survey after the class. All students were told to complete the surveys and they returned them to the researcher.
The instrument used was a questionnaire written by the researchers. Questionnaires were to determine attitudes towards participation in academic dishonesty. After that, a group focus discussion in each class was undertaken to justify the respondent's results of the survey.

\section{Results}

Table 1 Profile of the Respondents

\begin{tabular}{|c|c|c|c|c|c|}
\hline \multicolumn{2}{|c|}{ Characteristics } & $\Sigma$ & \multicolumn{2}{|c|}{ Charachetristics } & $\Sigma$ \\
\hline \multirow[t]{3}{*}{ Gender } & Male & 31 & \multirow[t]{3}{*}{ Age } & 18 y.o & 4 \\
\hline & \multirow[t]{2}{*}{ Female } & \multirow[t]{2}{*}{57} & & 19 y.o. & 75 \\
\hline & & & & 20 y.o. & 9 \\
\hline \multirow[t]{5}{*}{ GPA } & $<2$ & 2 & \multirow[t]{2}{*}{ Status } & Married & 2 \\
\hline & $2.1-2.5$ & 21 & & Single & 86 \\
\hline & $2.6-2.9$ & 31 & \multirow[t]{3}{*}{ Ethicity } & Javanese & 63 \\
\hline & $3-3.49$ & 22 & & Non & \multirow[t]{2}{*}{25} \\
\hline & $>3.5$ & 12 & & Javanese & \\
\hline
\end{tabular}

Table 1 indicated that the majority of respondents were female and mostly they were 19 years old. Two students were married and the respondents were perdominatly Javanese. This profile gave a picture of the characteristices of the respondents.

Here are lists of cheating mode that respondent experienced when doing the examinations. Respondents had to choose their options by ticking yes or no in each of the statement. The result was shown in table 2 . 
Table 2. Kinds of Cheating

\begin{tabular}{|c|c|}
\hline No & Statements \\
\hline 1 & Working in a group on a homework assignment that was assigned as individual work. \\
\hline 2 & $\begin{array}{l}\text { Asking another student for the answers to an examination that he/she had previously taken and } \\
\text { you are about to take. }\end{array}$ \\
\hline 3 & Copying from another student during a quiz or examination. \\
\hline 4 & Delay taking an exam or turning in a paper by using a fictitious excuse. \\
\hline 5 & Copying a paper from a file and presenting it as your own original work. \\
\hline 6 & Copying from a "cheat sheet" during a quiz or examination. \\
\hline 7 & Looking at an exam from a test file when the teacher does not permit such copies to exist. \\
\hline 8 & $\begin{array}{l}\text { Marking two answers on a hand scored test, so that the choice is unclear hoping that the teacher } \\
\text { will assume a correct response was intended. }\end{array}$ \\
\hline 9 & $\begin{array}{l}\text { Having another student write a paper or homework assignment that you then present as your own } \\
\text { original work. }\end{array}$ \\
\hline 10 & $\begin{array}{l}\text { Changing a response after a paper/exam/quiz was graded, and then reporting that there had been a } \\
\text { mis-grade. }\end{array}$ \\
\hline 11 & Taking an exam for another student. \\
\hline
\end{tabular}

The kinds of cheating that most students have ever done were asking another student for the answers to an examination that he/she had previously taken and you are about to take; and copying from another student during a quiz or examination. This finding is similar to the one found in the Diekhoffet al. reserach (1996). There were 73 students $(87.5 \%)$ did statement no: 2 ;and 76 students (86.4\%) for statement no: 3 . Meanwhile, statement no: 11 i.e., taking an exam for another students, had the lowest rank (2.3\%).

During the discussion, several findings were founds as follows. The general perception is that cheating is widespread. The respodents believe that cheating is more prevalent and accepted today. This is in line with the finding of Haines et.al. (1991). The perception is also that cheating is changing. Cheating is more widespread at the universities. Less social disapproval and increased competition for spots in graduate schools have made students more willing to do whatever it took to get the grades. This opinion is like Newsteadet.al. (1993) finding.The faculty stopped paying serious attention to cheating as they felt the need to focus more on problems such as campus safety.

\section{Discussion}

Academic Dishonesty has increased to be a problem bigger than ever before. This is like the assumption of MsCabe and Trevino (1993). More students are risking the consequences of being caught, all for making the grade. Although cheating in the academic world is nothing new to the academic faculty of all educational levels. This statement is similar to the one of Diekhoffet.al. (1999). The educational system has had to stay up to par with all the new ways of cheating found by students today.

In the past years, a principle and parent meeting for cheating would have been a rare occasion, because of 
moral family beliefs and values. These moral boundaries were most always carried on through the college years. On the occasions that such types of cheating arose, punishment was of a less harsh price to pay. This finding is in accordance with the opinion of Aiken (1991).

Through the recent trend of much higher cheating, there had to be changes in expanding and enforcing the harsher measures of punishments for cheating. Just as any other immoral issue out of control, laws, rules and punishments will be changed accordingly. Newsteadet.al. (1993) aggree with that stamement. When too many people start breaking down the moral fibers, it is then seen as a threat to society as a whole. By defining the real reasons as to why cheating occurs; there now is the findings of class stratifications and ages, no longer being predictable.

\section{Conclusion}

It can be concluded that the temptation to cheat increases due to pressure for high grades. When students are in a class that builds on previous information, cheating makes it difficult to understand concepts presented later.

The most frequent types of cheating done by students are to ask another student for the answer to an exam; and to copy from another students during the exam. It seems that the faculty see cheating as a common problem that cannot be stopped.

The traditional values, such as gotongroyong, sadulur, damaiand rasa kekeluargaancan deterirate the situation as students often use these aspects for an excuse for cheat.ing in an exam.

\section{References}

[1] Aiken, L.R. (1991). Detecting, understanding, and controlling for cheating on tests. Research in Higher Education, 32, 725-736.

[2] Anderson,B. (1965). Mythology and the Tolerance of the Javanese.New York: Cornell University.

[3] Diekhoff,G.M., LaBeff,E.E., Clark,R.E., Williams,L.E., Francis,B., \&Haines,V.J. (1996). College cheating: Ten years later. Research in Higher Education, Research in Higher Education, 37, 487-502.

[4] Diekhoff,G.M., LaBeff,E.E., Shinohara,K., \&Yasukawa,H. (1999). College Cheating in Japan and the United States. Research in Higher Education, 40, 343-353.

[5] Geerzt, H. (1961). The Javanese Family.. New York: The Free Press of Glencoe

[6] Guiness, P. (1986). Harmony and Hierarchy in a Javanese Kampung. Singapore: Oxford University Press.

[7]Haines,V.J., Diekhoff,G.M., LaBeff, E.E.,\&Clark, R. E. (1986). College Cheating: Immaturity, Lack of Commitment, And The Neutralizing Attitude. Research in Higher Education, 25, 342-354.

[8]Howard, R.M., \& Davies,L.J. (2009). Plagiarism In The Internet Age. Educational Leadership, 66 (6), 64-67

[9] Jones,L.R. (2001). Academic Integrity \& Academic Dishonesty: A Handbook About Cheating and Plagiarism. Florida, U.S.A:Florida Institute of Technology.

[10] Koentjaraningrat.(1990). Javanese Culture. Singapore: Oxford University Press.

[11] McCabe,D.L., \&Trevino,L.K. (1993). Academic

Dishonesty: Honor Codes And Other Contextual 
Influences. Journal of Higher Education, 64, 520538.

[12] Newstead, S. E., Franklyn-Stokes, A., \&Armstead, P. (1996). Individual differences in student cheating. Journal of Educational Psychology, , 88: 229-241.

[13] Poedjosoedarmo,S. (1982). Javanese Influence on Indonesian, Canberra: The Australia National University
[14] Sairin,S. Javanese Trah. (1982). Yogyakarta: GadjahMadaUniversty Press.

[15] Smith-Hefner,N.J. (1988).Women and Politeness: The Javanese Example. Language and Society, 17, 355-354.

[16] Suharno.(1982). A Descrptive Study of Javanese. Canberra: The Australian National University. 